\title{
Degradation of atrazine photoinduced by Fe(III)-pyruvate complexes in the aqueous solution
}

\author{
Changbo Zhang a,b, Lei Wang ${ }^{c}$, Gang Pan ${ }^{c}$, Feng Wu ${ }^{a, *}$, Nansheng Deng ${ }^{a}$, Gilles Mailhot ${ }^{b}$, \\ Hana Mestankova ${ }^{\text {b }}$, Michele Bolte ${ }^{\mathrm{b}}$ \\ a School of Resource and Environmental Science, Wuhan University, Wuhan 430079, PR China \\ b Laboratoire de Photochimie Moléculaire et Macromoléculaire, UMR 6505 CNRS, Université Blaise Pascal de Clermont-Ferrand, F-63177 Aubière Cedex, France \\ ' State Key Laboratory of Environmental Aquatic Chemistry, Research Center for Eco-environmental Sciences, Chinese Academy of Sciences, Beijing 100085, PR China
}

\section{A R T I C L E I N F O}

\section{Article history:}

Received 19 November 2008

Received in revised form 17 February 2009

Accepted 5 April 2009

Available online 14 April 2009

\section{Keywords:}

$\mathrm{Fe}(\mathrm{III})$

Pyruvate

Atrazine

Hydroxyl radical

Photodegradation

\begin{abstract}
A B S T R A C T
The composition and photochemical properties of the Fe(III)-Pyr complexes in the aqueous solution was studied in this work. Fe(III) was complexed by Pyr in the ratio of 1:3. The photochemical processes occurred in the $\mathrm{Fe}$ (III)-Pyr system was studied in detail. Fe(II) was the main intermediate product. DMPO was used as scavenger to determine the active radicals, such as ${ }^{\bullet} \mathrm{OH}, \mathrm{CO}_{3}{ }^{--}, \mathrm{CO}_{2}{ }^{--}, \mathrm{H}^{\bullet}$ and $\mathrm{RCO}_{2} \bullet$ by ESR. Photodegradation of atrazine induced by the photolysis of Fe(III)-Pyr was studied and the reaction kinetics fitted the first order reaction. Parameters such as $\mathrm{pH}$, the initial concentrations of Fe(III), pyruvate (Pyr) and atrazine were all investigated. Photoproducts were detected by the LC-MS and the photodegradation scheme was proposed. ${ }^{\bullet} \mathrm{OH}$ radical was the main pathway of atrazine degradation.
\end{abstract}

(c) 2009 Elsevier B.V. All rights reserved.

\section{Introduction}

Carboxylic acids have received considerable attention as one of the most common dissolved organic compounds in natural environment $[1,2]$. They were also considered to be one of the dominant classes of organic compounds found in the atmosphere in a variety of phases [3-8]. They have been found in rainwater [9-12], snow and ice [13], on aerosol particles [14-17] and in the gas phase [18-20]. Pyruvic acid was one of the most abundant ketoacids presented in the atmosphere. Its presence has been reported in aerosols, rainwater and in the gas phase in urban atmosphere as well as in remote continental and marine areas. Andreae et al. [21] demonstrated that it was a product of the photochemical oxidation of natural organic compounds such as isoprene and cresols. It was expected to play a role in the precipitation acidity [22]. Available data indicated that pyruvic acid was lost in the gas phase mainly through photolysis. Mellouki and $\mathrm{Mu}$ [23] measured the reaction rate constant of ${ }^{\bullet} \mathrm{OH}$ with pyruvic acid $\left(\mathrm{CH}_{3} \mathrm{C}(\mathrm{O}) \mathrm{C}(\mathrm{O}) \mathrm{OH}\right)$ in the gas phase. The value was $k_{\mathrm{PA}}=(1.2 \pm 0.4) \times 10^{-13} \mathrm{~cm}^{3}$ molecule ${ }^{-1} \mathrm{~s}^{-1}$ at $298 \mathrm{~K}$. They also detected $\bullet \mathrm{OH}$ with a relative quantum yield of $5 \pm 3 \%$ by the direct photolysis of pyruvic acid. However, the study of the ratio composition of the pyruvic acid complex with $\mathrm{Fe}(\mathrm{III})$ and

\footnotetext{
* Corresponding author. Tel.: +86 27 68778511; fax: +86 2768778511 .

E-mail address: fengwu@whu.edu.cn (F.Wu).
}

its detailed photolysis processes were unavailable from literature. In this work, we studied the ratio of Fe(III)-Pyr complexes and its photochemical properties.

Atrazine (2-chloro-4-ethylamino-6-isopropylamino-1,3,5triazine) was used as a model compound. It was a selective inside-absorbing herbicide which can be used in the fields of corn, sorghum, orchard and forest, controlling broad-leaf and grassy weeds [24]. It was not readily biodegradable and presented a relatively high persistence in soils and even reaches the groundwater. Its solubility in water was low $\left(1.61 \times 10^{-4} \mathrm{M}\right)$ and did not depend on $\mathrm{pH}$ [25]. Atrazine, like other herbicides of the $S$-triazine group, was barely oxidized by ozone [26]. Many methods have been developed to remove atrazine, including adsorption on activated carbon and advanced oxidation processes. These comprised both homogeneous and heterogeneous systems, for example the UV photolysis of hydrogen peroxide [27,28], the reaction of hydrogen peroxide with ozone [29] or $\mathrm{Fe}(\mathrm{II})$ [30], ionizing radiation, ultrasound [31], photolysis by $\mathrm{TiO}_{2}$ colloidal particles [32-35] and $\mathrm{Fe}(\mathrm{III}) /$ oxalate systems [36]. There was no report that had been published with respect to the photodegradation of atrazine in the Fe(III)-Pyr systems.

The aims of this study were as follows: (1) characterizing the physicochemical and photochemical properties of Fe(III)-Pyr complex; (2) determining the active oxygen species and proposing the photochemical processes that happened in the Fe(III)-Pyr system; (3) studying the photochemical degradation of atrazine induced by 
the Fe(III)-Pyr system and examining several factors that controlled the kinetics of atrazine degradation.

\section{Experimental materials and methods}

\subsection{Chemicals and preparation of solutions}

$\mathrm{FeCl}_{3} \cdot 6 \mathrm{H}_{2} \mathrm{O}, \quad \mathrm{CH}_{3} \mathrm{COCOONa}$, atrazine, 1,10-phenanthroline, ammonium acetic acid, $\mathrm{K}_{3} \mathrm{Fe}\left(\mathrm{C}_{2} \mathrm{O}_{4}\right)_{3}, \mathrm{FeSO}_{4}, \mathrm{H}_{2} \mathrm{SO}_{4}, \quad 5,5-$ dimethylpyrroline- $N$-oxyde (DMPO), acetonitrile, $\mathrm{HCl}$ and $\mathrm{NaOH}$ were all analytical grade and used without further purification. Ferric chloride was used as $\mathrm{Fe}(\mathrm{III})$ sources. Sodium pyruvate was used as pyruvate source. All of the solutions were prepared by doubly distilled water.

Great care was taken to prepare stock solutions of Fe(III). In order to prevent precipitation of $\mathrm{Fe}(\mathrm{III})$, an appropriate weight of ferric chloride was dissolved in hydrochloric acid ( $1 \mathrm{~N}$, a few $\mathrm{mL}$ ) and then added to an appropriate volume of doubly distilled water to get the desired concentration of $\mathrm{Fe}(\mathrm{III})$ and $\mathrm{pH}$ 3.0.

\subsection{Determination of the composition of the Fe(III)-Pyr complex}

Molar ratio method was used to determine the composition of $\mathrm{Fe}(\mathrm{III})-\mathrm{Pyr}$ complexes. This method was based on the spectrophotometric analysis. The concentration of metal ions $\left(C_{\mathrm{M}}\right)$ in aqueous solution was kept constant and the concentration of the relative acid $\left(C_{\mathrm{L}}\right)$ was increased in the experiment. The absorbance of the aqueous solution increased with the increasing of the acid concentration until it became stable, which indicated that the metal ions were totally coordinated by the acids.

The stoichiometry of the complex corresponded to the ratio $\left(C_{\mathrm{L}} / C_{\mathrm{M}}\right)$ where the absorbance began to be stable; no more increasing was measured with the supplementary addition of acids.

\subsection{Measurement of $\mathrm{Fe}(\mathrm{II})$}

Under irradiation, $\mathrm{Fe}(\mathrm{II})$ was formed in aqueous solutions in the presence of $\mathrm{Fe}(\mathrm{III})$. The concentration of $\mathrm{Fe}(\mathrm{II})$ was determined by complexometry with 1,10-phenanthroline taking $\varepsilon_{510 \mathrm{~nm}}=1.118 \times 10^{4} \mathrm{~L} \mathrm{~mol}^{-1} \mathrm{~cm}^{-1}[37,38]$. At different irradiation times intervals, $2 \mathrm{~mL}$ of the samples were added to $5 \mathrm{~mL}$ flask, followed by the addition of $0.5 \mathrm{~mL}$ of 1,10 -phenanthroline $(0.1 \%$ by mass) and $1 \mathrm{~mL}$ of ammonium acetate buffer ( $\mathrm{pH} 4.5)$. After agitation, the solutions were kept in the dark for $1 \mathrm{~h}$ and then the UV-vis measurement was carried out at $510 \mathrm{~nm}$ by UV-120-02 spectrophotometer (Shimadzu).

Quantum yields of Fe(II) generation were determined by ferrioxalate potassium actinometer.

\subsection{Photodegradation experiments}

Irradiation experiments were carried out in a $250 \mathrm{~mL}$ homemade cylindrical reactor with a diameter of $10 \mathrm{~cm}$. The metal halide lamp $(\lambda \geq 350 \mathrm{~nm}, 250 \mathrm{~W})$ was used as the irradiation source, which was surrounded by a water jacket and cooling water was used to keep the reaction solutions at room temperature ( $298 \pm 1 \mathrm{~K})$. In order to get the complexed solutions, Fe(III)-Pyr were magnetically stirred for $1 \mathrm{~h}$ before adding atrazine solution. The $\mathrm{pH}$ of the aqueous solutions was adjusted to the desired value by $\mathrm{HCl}(1 \mathrm{~N})$ or $\mathrm{NaOH}(1 \mathrm{~N})$. All the reaction solutions were prepared and kept in the dark prior to irradiation. All of the experiments were carried out three times in this work and the error bar represented the standard error.

\subsection{Analysis}

At different time intervals during the irradiation, samples were collected and analyzed by HPLC. Atrazine was monitored at $240 \mathrm{~nm}$ by HPLC (Shimadzu LC-10AT) with a UV-vis detector (Shimadzu SPD-10A). The mobile phase was acetonitrile/water mixture (50/50, $\mathrm{v} / \mathrm{v}$ ) at a flow rate of $1.0 \mathrm{~mL} \mathrm{~min}^{-1}$ using Kromasil, KR100-5C18 column $(250 \mathrm{~mm} \times 4.6 \mathrm{~mm}, 5 \mu \mathrm{m})$. LC-MS studies were carried out with a Waters (Alliance 2695) HPLC system coupled to a Quattro LC triple quadrupole mass spectrometer (Micromass, Manchester, UK) equipped with a pneumatically assisted electrospray ionization source (ESI). Data acquisition and processing were performed by MassLynx NT 3.5 system.

\subsection{Electron spin resonance (ESR) spectroscopy}

ESR spectra were recorded at room temperature on a Bruker ER 200D, X BAND spectrometer operating at $9.6 \mathrm{GHz}$ and a cavity equipped with a quartz flat cell designed for liquid samples. Typical spectrometer parameters were: scan range, $100 \mathrm{G}$; centre field set, $3440 \mathrm{G}$; time constant, $327 \mathrm{~ms}$; scan time, 167 s; modulation amplitude, $1.5 \mathrm{G}$; modulation frequency, $100 \mathrm{kHz}$; receiver gain, $1.25 \times 10^{6}$; and microwave power, $25.2 \mathrm{~mW}$, frequency, $9.64 \mathrm{GHz}$.

The 5,5-dimethylpyrroline- $N$-oxyde (DMPO) was used as a scavenger in this study. The irradiation experiments were carried out under a Xe-Hg lamp with two different filters. Cooling water was used to maintain the reaction at room temperature.

\section{Results and discussion}

\subsection{Study of the physicochemical properties of Fe(III)-Pyr complex}

UV-vis spectra of different aqueous solutions were shown in Fig. 1(a). The absorption spectra of organic complex iron species were shifted toward the visible and its charge transfer band strongly
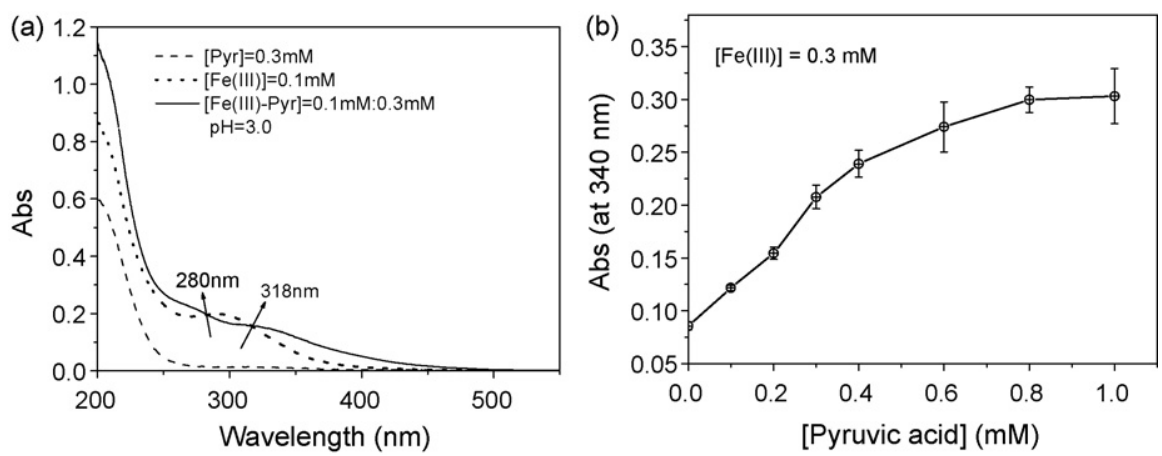

Fig. 1. Spectrophotometric evolution of the Fe(III)-Pyr complex as a function of Pyr concentration. 


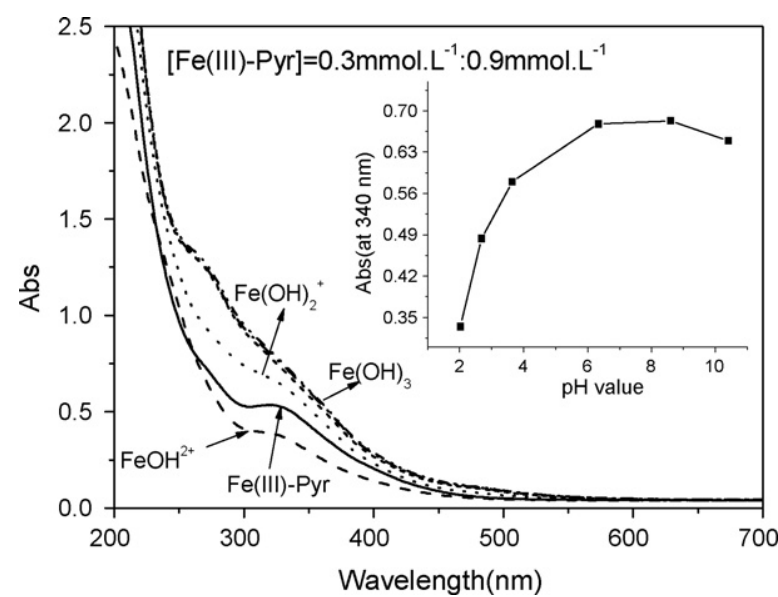

Fig. 2. UV-vis spectra of $\mathrm{Fe}(\mathrm{III})-\mathrm{Pyr}$ complex as function of pH value.

overlapped with the solar UV spectrum (318-500 nm). Therefore, it could be easily photolyzed and the absorbance was higher than hydrated iron species or Pyr, which led the Fe(III)-Pyr system to use the light energy more efficiently.

The composition of the Fe(III)-Pyr complex was studied using molar ratio method. The concentration of Fe(III) ions was kept constant at $0.3 \mathrm{mM}$ and then increased the Pyr from 0 to $1.0 \mathrm{mM}$. Experiments were carried out three times. Fig. 1(b) presented the evolution of the Fe(III)-Pyr complex as a function of Pyr concentration. The absorbance became stable when the concentration of the Pyr got above $0.8 \mathrm{mM}$. It indicated that the $\mathrm{Fe}(\mathrm{III})$ ions were complexed by Pyr with the molar ratio equal to $1: 3$. The stability of Fe(III)-Pyr complex was studied in the dark at room temperature. The complex was stable in the aqueous solutions under our experimental condition ( $\mathrm{pH}$ 3.0). Results showed that the $\mathrm{pH}$ was an important parameter for the stability of the complex and its speciation (Fig. 2). At $\mathrm{pH}<2.0,\left[\mathrm{Fe}\left(\mathrm{H}_{2} \mathrm{O}\right)_{6}\right]^{3+}$ became the main species in the solutions while from $\mathrm{pH} 2.5$ to 5.0 the Fe(III)-Pyr complex was the major species. From 5.0 to $6.0, \mathrm{Fe}(\mathrm{OH})_{2}{ }^{+}$gradually became the main species but this species rapidly disappeared with time. When $\mathrm{pH}>7.0$, the precipitation of $\mathrm{Fe}(\mathrm{III})$ was observed. The absorbance of the solution was intervened by the precipitate.

\subsection{Photochemical properties of Fe(III)-Pyr complex}

\subsubsection{Fe(II) formation in the $\mathrm{Fe}(\mathrm{III})-\mathrm{Pyr}$ system under irradiation}

$\mathrm{Fe}(\mathrm{II})$ was an important intermediate product generated by the photolysis of $\mathrm{Fe}(\mathrm{III})-\mathrm{Pyr}$ complexes under irradiation. The concentration of $\mathrm{Fe}(\mathrm{II})$ was detected in the aqueous solutions containing $\mathrm{Fe}(\mathrm{III})$ or $\mathrm{Fe}(\mathrm{III})-\mathrm{Pyr}$ complexes. Irradiation experiments were car-
Table 1

Quantum yields of $\mathrm{Fe}(\mathrm{II})$ in the aqueous solutions with $0.3 \mathrm{mM}$ $\mathrm{Fe}(\mathrm{III}), 0.3 \mathrm{mM} \mathrm{Fe}(\mathrm{III})-\mathrm{Pyr}$ complexes and the initial $\mathrm{pH}$ value was 3.0. $\left(\lambda_{\text {irr }}=365 \mathrm{~nm}\right)$.

\begin{tabular}{ll}
\hline Different reaction systems & $\Phi_{\mathrm{Fe}(\mathrm{II})}$ \\
\hline$[\mathrm{Fe}(\mathrm{III})]=0.3 \mathrm{mM}$ & 0.027 \\
{$[\mathrm{Fe}(\mathrm{III})-\mathrm{Pyr}]=0.3 \mathrm{mM} / 0.9 \mathrm{mM}$} & 0.21 \\
\hline
\end{tabular}

ried out under metal halide lamp. As it can be realized by comparing the results in Fig. 3(a) and (b), we got higher concentration of Fe(II) in the presence of Pyr than without Pyr. At different pH 3.0, 4.0 and 5.0 , the same trend was noticed. Quantum yields of $\mathrm{Fe}(\mathrm{II})$ generation was also determined in this work, observing a $\Phi_{\mathrm{Fe}(\mathrm{II})}$ seven times higher in the presence of Fe(III)-Pyr complex than Fe(III) (Table 1). It was demonstrated that Pyr could enhance the photoreduction process of $\mathrm{Fe}(\mathrm{III})$ and photocycling of $\mathrm{Fe}(\mathrm{III}) / \mathrm{Fe}(\mathrm{II})$.

The $\mathrm{pH}$ was a crucial parameter and it could affect the competition between the reaction of $\mathrm{Fe}(\mathrm{III}) / \mathrm{Fe}(\mathrm{II})$ and the distribution of $\mathrm{Fe}(\mathrm{III})$ species in the Fenton and photo-Fenton-type systems [39]. Fig. 3 also presented a decrease of the Fe(II) generation with the increase of $\mathrm{pH}$ value. At high $\mathrm{pH}$, the precipitation of $\mathrm{Fe}(\mathrm{III})$ was happened. Thus Fe(III) was less available in the water. And high $\mathrm{pH}$ was also unfavorable for the photocycling of $\mathrm{Fe}(\mathrm{III}) / \mathrm{Fe}(\mathrm{II})$.

\subsubsection{Photolysis of Fe(III)-Pyr complex}

In order to understand the photochemical processes in the $\mathrm{Fe}(\mathrm{III})-\mathrm{Pyr}$ system, experiments were carried out by ESR spin trapping techniques. DMPO $\left(1 \mathrm{mg} \mathrm{mL}^{-1}\right)$ was used as scavenger for different radicals formed in the aqueous solution. The irradiations were carried out directly in the cavity ESR using a Xe-Hg lamp with two different filters. At short wavelength irradiation $(\lambda \geq 280 \mathrm{~nm})$, the four-line ESR spectrum $(1: 2: 2: 1)$ of the DMPO-OH spin adduct was observed at the beginning of the irradiation in the Fe(III)-Pyr system (Fig. 4(a)). For longer irradiation time a more complicated signals were observed. The ESR signals were different as a function of irradiation wavelength. These signals were attributed to the combination of the classical 1:2:2:1 signal of $\bullet \mathrm{OH}$ adduct and of the $\mathrm{CO}_{3}{ }^{-}-$adduct (Fig. 4(b)). At long irradiation wavelength $(\lambda \geq 350 \mathrm{~nm})$, a nice dedoubled triplet signal was observed and this signal corresponded to a mixture of radical types $\mathrm{CO}_{2}{ }^{--}$and $\mathrm{RCO}_{2}{ }^{\bullet}$ adducts trapped by the DMPO (Fig. 4(c)) [40]. $\mathrm{H}^{\bullet}$ radical reacted very fast with oxygen to form $\mathrm{HO}_{2} \bullet$ radicals, which led to the formation of $\mathrm{H}_{2} \mathrm{O}_{2}$. Moreover, this recombination was more efficient when involving the basic and the acid forms of the radicals $\mathrm{HO}_{2} \bullet / \mathrm{O}_{2}{ }^{\bullet-}$ [41].

The photolysis mechanism of the Fe(III)-Pyr system was proposed in Fig. 5. In this process, Fe(III)-Pyr was excited under irradiation which led to the photolysis of iron complex with the formation of $\mathrm{Fe}(\mathrm{II})$ species and the excited state Pyr. In the presence
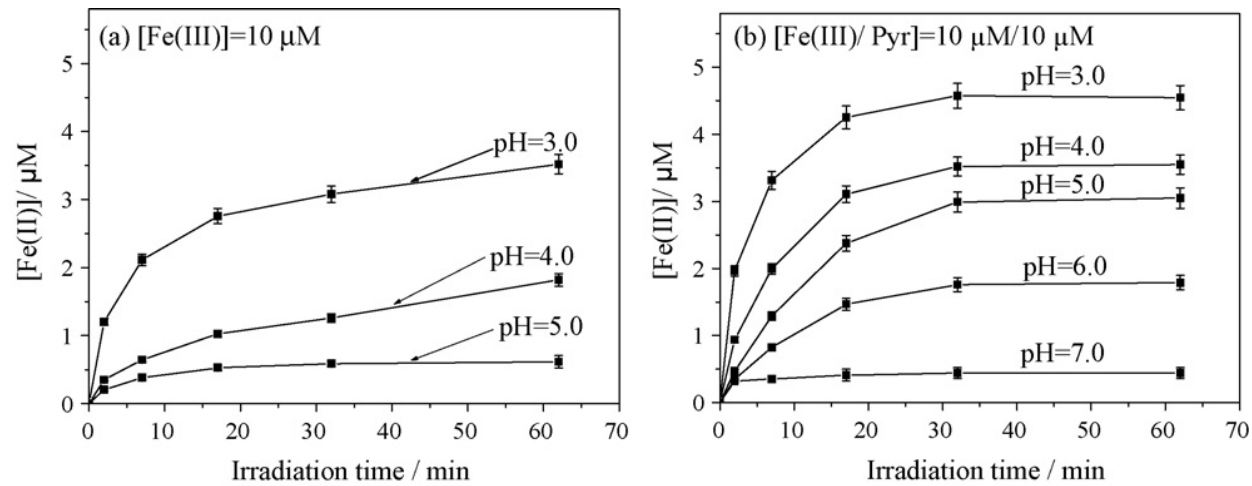

Fig. 3. $\mathrm{Fe}(\mathrm{II})$ photogeneration in the water with (a) $[\mathrm{Fe}(\mathrm{III})]=10 \mu \mathrm{M}$ and (b) $[\mathrm{Fe}(\mathrm{III}) / \mathrm{Pyr}]=10 \mu \mathrm{M} / 10 \mu \mathrm{M}$ as function of pH. 

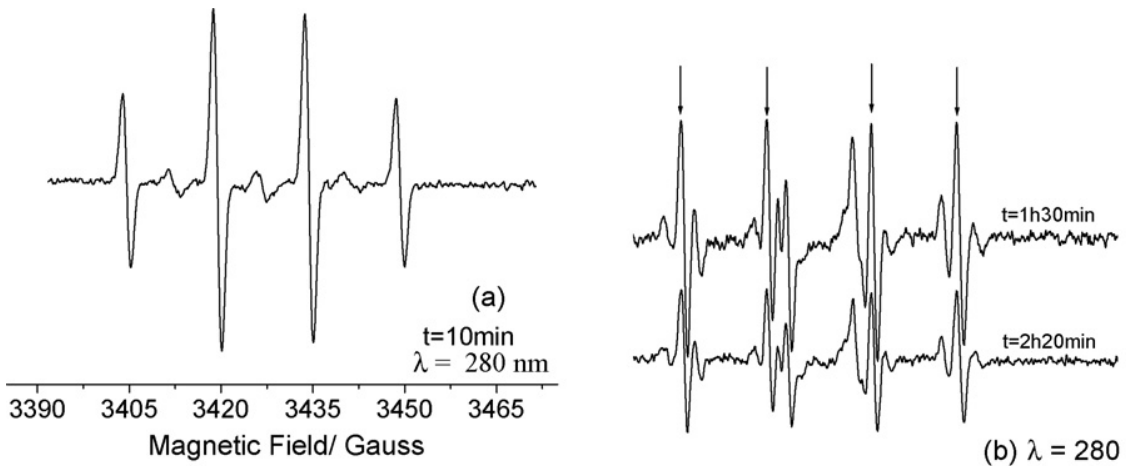

(b) $\lambda=280 \mathrm{~nm}$

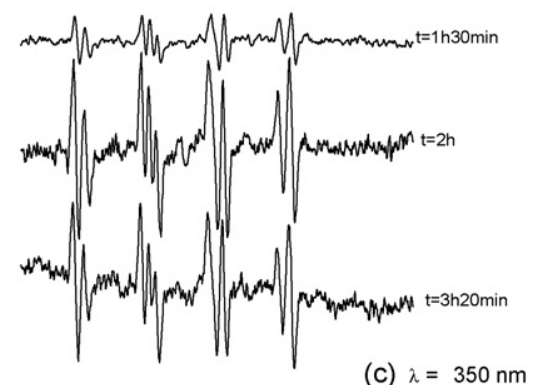

Fig. 4. ESR spectra of the aqueous solution with $1 \mathrm{mg} \mathrm{mL}^{-1}$ of DMPO and $0.3 \mathrm{mM}$ of Fe(III)-Pyr complex at $\mathrm{pH} 3.0$ under irradiation.

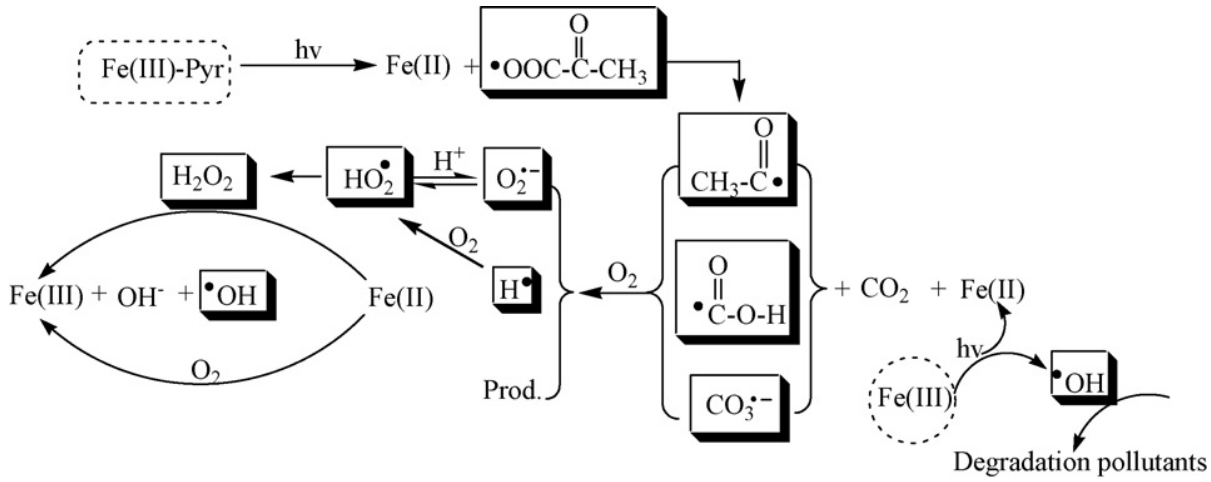

Fig. 5. Proposed photolysis processes of $\mathrm{Fe}(\mathrm{III}) / \mathrm{Pyr}$.

of the dissolved oxygen, the excited state Pyr underwent a further decomposition with the formation of ${ }^{\bullet} \mathrm{OH},{ }^{\bullet} \mathrm{COOH}, \mathrm{CO}_{3}{ }^{\bullet-}, \mathrm{H}^{\bullet}$ and $\mathrm{HO}_{2} \bullet[40,42]$. At the same time, $\mathrm{Fe}(\mathrm{II})$ was again oxidized into $\mathrm{Fe}(\mathrm{III})$. The photocycling process of $\mathrm{Fe}(\mathrm{III}) / \mathrm{Fe}(\mathrm{II})$ existed in the system. $\mathrm{Fe}(\mathrm{II})$ generation has been discussed above. In the water with $10.0 \mu \mathrm{M}$ $\mathrm{Fe}(\mathrm{III})$ and $30.0 \mu \mathrm{M}$ Pyr at $\mathrm{pH} 3.0,{ }^{\circ} \mathrm{OH}$ was produced following a 160 min irradiation in the amount of $34.0 \mu \mathrm{M}$. The generation rate constant of $\bullet \mathrm{OH}$ was $0.21 \mu \mathrm{ML}^{-1} \mathrm{~min}^{-1}$ with a quantum yield of generation of 0.02 [43].

\subsection{Photodegradation of atrazine in the aqueous solutions}

The photodegradation of atrazine was studied in this work. The control experiments were carried out in the systems with $20.0 \mu \mathrm{M}$ $\mathrm{Fe}(\mathrm{III}), 20.0 \mu \mathrm{M}$ Pyr and $20.0 \mu \mathrm{M} / 60 \mu \mathrm{M}$ Fe(III)-Pyr complex. The initial concentration of atrazine was $10.0 \mathrm{mg} \mathrm{L}^{-1}$. The dark reaction was carried out to keep the mixture of atrazine, Fe(III) and pyruvate in the dark. From the results in Fig. 6, no degradation of atrazine was observed in the 150 min dark control and light proved to be an essential element for the degradation of atrazine. Direct irradiation of $10.0 \mathrm{mg} \mathrm{L}^{-1}$ atrazine showed no degradation of atrazine. The photodegradation efficiency of atrazine was higher in the aqueous solution with $\mathrm{Fe}(\mathrm{III})-\mathrm{Pyr}$ complex than in the one only containing Pyr or Fe(III). Although ${ }^{\bullet} \mathrm{OH}$ radicals could be produced by the direct photolysis of $\mathrm{Fe}(\mathrm{III})$ and Pyr, the amount of the radicals produced

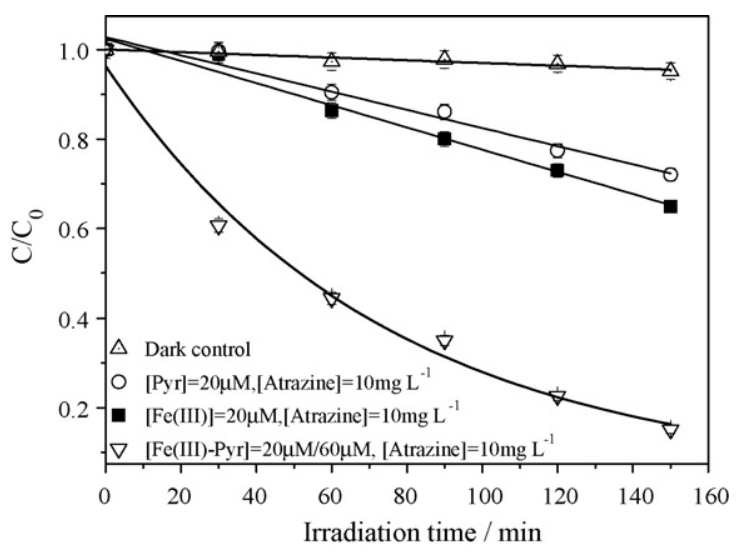

Fig. 6. Photodegradation of atrazine under different conditions at $\mathrm{pH}$ 3.0. 

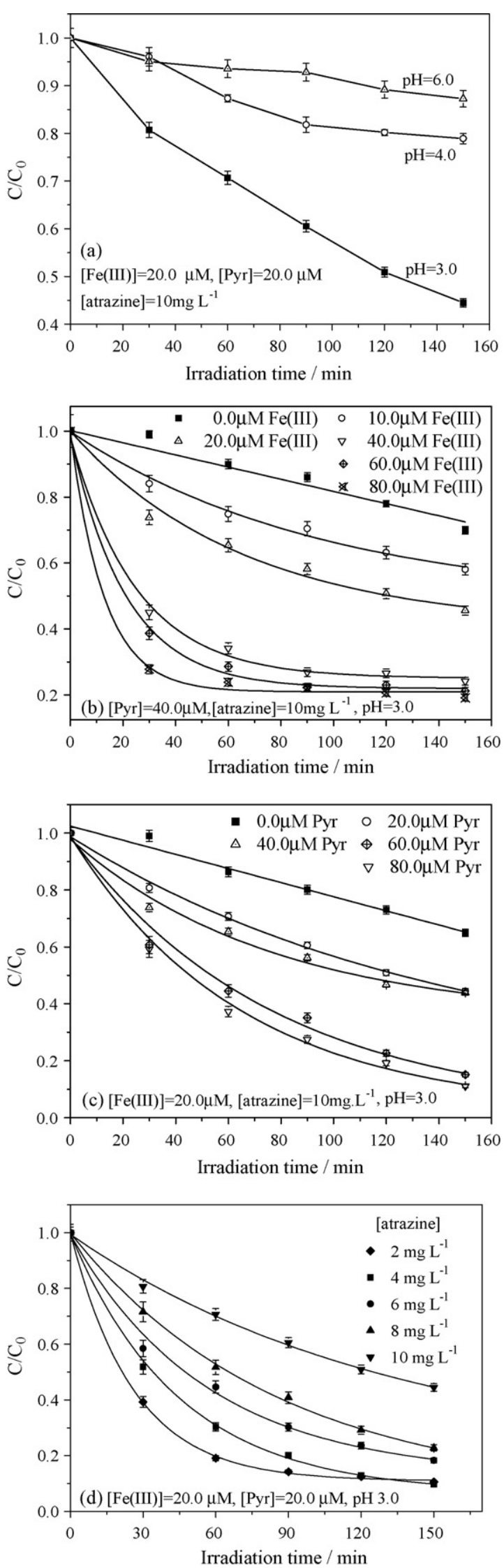

Fig. 7. Photodegradation of atrazine in the Fe(III)-Pyr systems, (a) at different pH values; (b) with different Fe(III) concentrations; (c) with different Pyr concentrations; (d) with different atrazine concentrations.
Table 2

Kinetics analysis of the photodegradation of atrazine.

\begin{tabular}{llc}
\hline System & $R$ & Initial Rate $\left(\mathrm{mg} \mathrm{L}^{-1} \mathrm{~min}^{-1}\right)$ \\
\hline Pyr $(\mu \mathrm{M})$ & $[\mathrm{Fe}(\mathrm{III})]=20.0 \mu \mathrm{M}$, [atrazine $]=10 \mathrm{mg} \mathrm{L}-1, \mathrm{pH} 3.0$ \\
10 & 0.9761 & 0.025 \\
20 & 0.9965 & 0.061 \\
40 & 0.9887 & 0.088 \\
60 & 0.9971 & 0.141 \\
80 & 0.9906 & 0.168 \\
& & \\
$\mathrm{Fe}(\mathrm{III})(\mu \mathrm{M})$ & {$[\mathrm{Pyr}]=40.0 \mu \mathrm{M},[$ atrazine $]=10 \mathrm{mg} \mathrm{L}-1, \mathrm{pH} 3.0$} \\
10 & 0.9704 & 0.021 \\
20 & 0.9870 & 0.091 \\
40 & 0.9972 & 0.314 \\
60 & 0.9981 & 0.388 \\
80 & 0.9881 & 0.637 \\
$\mathrm{pH}$ & {$[\mathrm{Fe}(\mathrm{III})-\mathrm{Pyr}]=20.0 \mu \mathrm{M} / 20.0 \mu \mathrm{M},[\mathrm{atrazine}]=10 \mathrm{mg} \mathrm{L}^{-1}$} \\
3.0 & 0.9966 & 0.061 \\
4.0 & 0.9695 & 0.029 \\
6.0 & 0.9574 & 0.011 \\
Atrazine $\left(\mathrm{mg} \mathrm{L}^{-1}\right)$ & {$[\mathrm{Fe}(\mathrm{III})-\mathrm{Pyr}]=20.0 \mu \mathrm{M} / 20.0 \mu \mathrm{M}, \mathrm{pH} 3.0$} \\
2.0 & 0.9997 & 0.069 \\
4.0 & 0.9993 & 0.087 \\
6.0 & 0.9942 & 0.097 \\
8.0 & 0.9989 & 0.088 \\
\hline
\end{tabular}

was less than in the Fe(III)-Pyr system given that the Fe(III)-Pyr complex overlapped with the solar UV spectrum (318 nm-500 nm), allowing the effective use of irradiation. After 150 min irradiation, nearly $85 \%$ atrazine had been degraded in the Fe(III)-Pyr system.

\subsection{Effect of $\mathrm{pH}$, initial Fe(III), Pyr and atrazine concentrations on the degradation of atrazine}

The $\mathrm{pH}$ as an important parameter was studied in the solution with $20 \mu \mathrm{M} \mathrm{Fe}(\mathrm{III})$ and $20.0 \mu \mathrm{M}$ Pyr and $10.0 \mathrm{mg} \mathrm{L}^{-1}$ atrazine under irradiation. Fig. 7(a) illustrates the experiment results. More than $55 \%$ of the atrazine degraded at $\mathrm{pH} 3.0$ after 150 min of irradiation. The photodegradation efficiency was low at high $\mathrm{pH}$. Only $20 \%$ of atrazine was degraded at $\mathrm{pH} 4.0$ and $13 \%$ at $\mathrm{pH} 6.0$ after $150 \mathrm{~min}$ of irradiation. It appeared that the $\mathrm{pH}$ played an important role in the photodegradation of atrazine. Acidic condition was favourable for the photocycling of $\mathrm{Fe}(\mathrm{III}) / \mathrm{Fe}(\mathrm{II})$ and the formation of active oxygen species, which was the main reason for the degradation of atrazine.

In this work, both $\mathrm{Fe}(\mathrm{III})$ and Pyr were the essential elements for the degradation of atrazine. It was necessary to study their effect on the reaction. Experiments were carried out to study the effect of different ratio of $\mathrm{Fe}(\mathrm{III}) / \mathrm{Pyr}$ on the photodegradation of atrazine. Fig. 7(b) presented results in the water with the following as the initial concentrations: $10.0 \mathrm{mg} \mathrm{L}^{-1}$ of atrazine, $40.0 \mu \mathrm{M}$

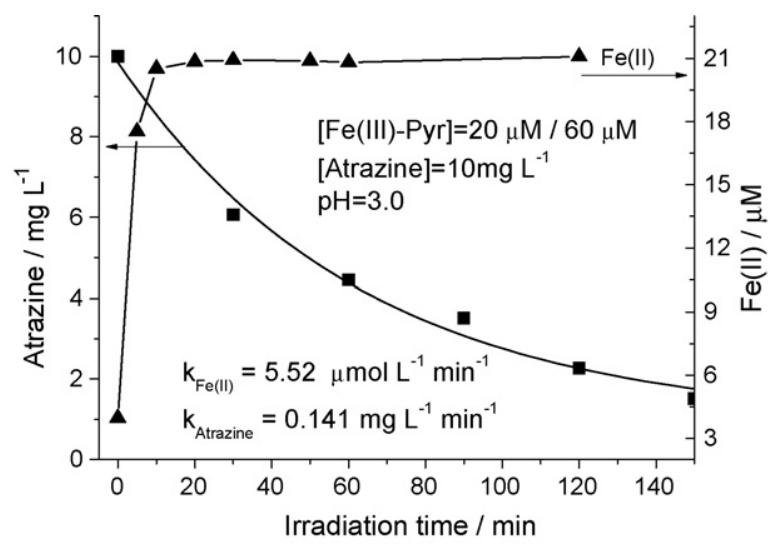

Fig. 8. Kinetics analysis of atrazine degradation and Fe(II) formation. 
of Pyr and different Fe(III) concentrations under irradiation at $\mathrm{pH}$ 3.0. With an increase of the initial concentration of $\mathrm{Fe}$ (III) from 0.0 to $80.0 \mu \mathrm{M}$, the photodegradation efficiency increased from $30 \%$ to $80 \%$ after 150 min irradiation. As presented in Fig. 7(c), the photodegradation efficiency of atrazine was also increased from $35 \%$ to $84 \%$ with the increase of Pyr concentration from 0.0 to $80.0 \mu \mathrm{M}$.
The enhancement of atrazine degradation efficiency was attributed to the high concentration of $\mathrm{Fe}(\mathrm{II})$ generated at high concentration of $\mathrm{Fe}(\mathrm{III})-\mathrm{Pyr}$, producing more active oxygen radicals in the system. For high activity of $\bullet \mathrm{OH}$ radicals, it was found that they were the most effective radicals for the pollutant degradation. From the photolysis processes of $\mathrm{Fe}(\mathrm{III})-\mathrm{Pyr}$, both reagents were found to be

(a) 100

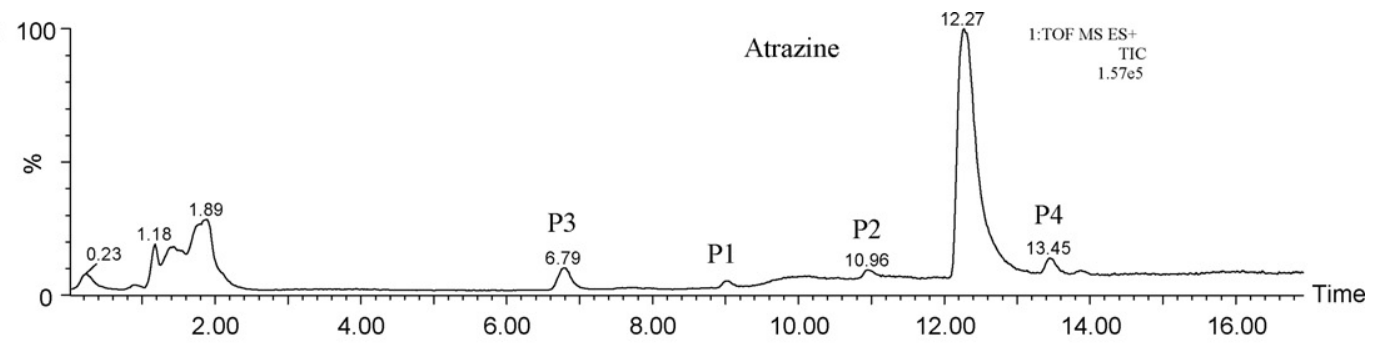

(b)
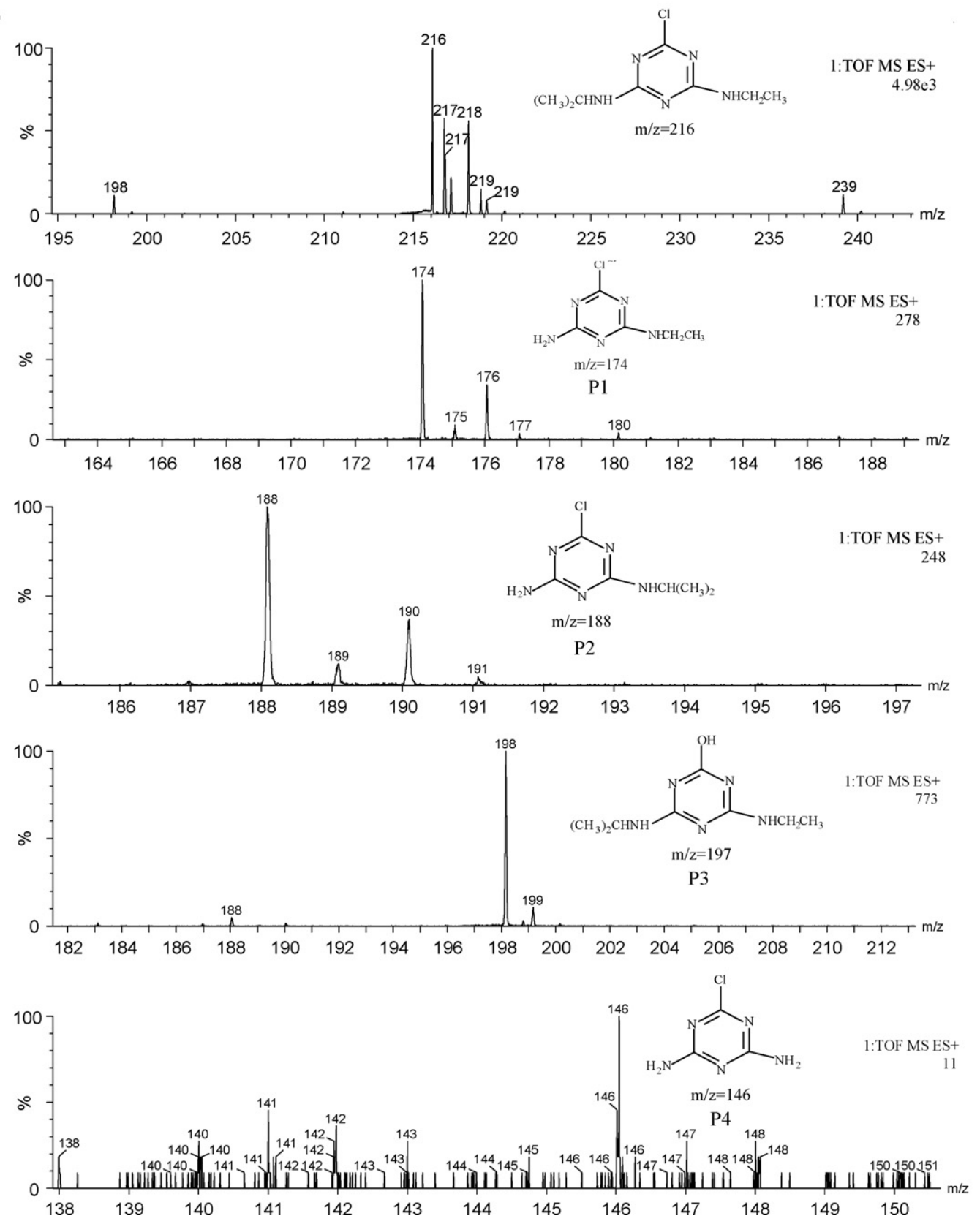

Fig. 9. LC-MS spectra of the atrazine degradation in Fe(III)-Pyr systems after $4 \mathrm{~h}$ of irradiation: (a) total ions chromatogram from LC-MS; (b) mass spectra of the main products. [Atrazine] $=10 \mathrm{mg} \mathrm{mL}^{-1}$, [Fe(III)/Pyr] $=10 \mu \mathrm{M} / 30 \mu \mathrm{M}, \mathrm{pH} 3.0$. 
essential to promote organic compounds degradation under this type of irradiation. Experiments were carried out under different atrazine initial concentrations in the Fe(III)-Pyr system at pH 3.0. Results are shown in Fig. 7(d). The photodegradation efficiency of atrazine decreased with the increase of atrazine concentration from 2.0 to $10.0 \mathrm{mg} \mathrm{L}^{-1}$.

According to the time evolution of atrazine under different conditions, we analyzed the reaction kinetics. The photodegradation of atrazine fitted well with the first order reaction kinetics. Results were presented in Table 2. Through comparing the formation of $\mathrm{Fe}(\mathrm{II})$ and degradation of atrazine under the same reaction conditions, it was concluded that the initial rate $k_{\mathrm{Fe}(\mathrm{II})}$ was higher than the $k_{\text {atrazine }}$ as shown in Fig. 8.

\subsection{Degradation products}

Under irradiation, atrazine was attacked by the active radicals, especially $\cdot \mathrm{OH}$ radicals, in the $\mathrm{Fe}(\mathrm{III})-\mathrm{Pyr}$ system. LC-MS was used to identify the intermediate photoproducts. The mass spectra were presented in Fig. 9. As expected the most intense peak was observed at $m / z 216$ deriving from atrazine, corresponding to $[\mathrm{M}+\mathrm{H}]^{+}$. The four main fragments-ions $m / z 174,188,197$ and 146 clearly demonstrated the formation of the degradation products 2-chloro-4-ethylamino-6-amino-1,3,5-triazine (P1), 2chloro-4-isopropylamino-6-amino-1,3,5-triazine (P2), 2-hydroxy4-ethylamino-6-isopropylamino-1,3,5-triazine (P3) and 2-chloro4,6-diamino-1,3,5-triazine (P4).

\section{Conclusions}

In this work, the formation and composition of Fe(III)-Pyr complex was first studied and $\mathrm{Fe}(\mathrm{III})$ was complexed by Pyr in the ratio of 1:3. This kind of complex was stable in the aqueous solution. Under irradiation, the photolysis of Fe(III)-Pyr complexes could represent the source of active oxygen radicals, such as $\bullet \mathrm{OH}, \mathrm{CO}_{3}{ }^{\bullet-}, \mathrm{CO}_{2}{ }^{\bullet-}, \mathrm{H}^{\bullet}$ and $\mathrm{RCO}_{2} \bullet$. In the $\mathrm{Fe}(\mathrm{III})-\mathrm{Pyr}$ system, free $\mathrm{Fe}$ (III) species could generate ${ }^{\bullet} \mathrm{OH}$ radicals through the reaction $\mathrm{Fe}(\mathrm{III})+\mathrm{H}_{2} \mathrm{O}+h v \rightarrow \mathrm{Fe}(\mathrm{II})+\bullet \mathrm{OH}+\mathrm{H}^{+} \cdot \bullet \mathrm{OH}$ radicals could also be generated by direct photolysis of pyruvic acid with a relative quantum yield of $5 \pm 3 \%$ [23]. Oxygen was always involved in the formation of active oxygen species. Acidic condition was favourable for this photochemical reaction.

$\mathrm{Fe}(\mathrm{III})-\mathrm{Pyr}$ complex could enhance the photodegradation of atrazine in the aqueous solution and under irradiation. High degradation efficiency was obtained at high concentrations of Fe(III)-Pyr and at low $\mathrm{pH}$. However, the photodegradation efficiency was decreased with the increase of initial atrazine concentration. Four kinds of photoproducts were identified in this work. This type of complexes could be formed in the natural aquatic environment due to the presence of carboxylic acids and iron. Thus, such complexes could influence the fate of inorganic and organic pollutants existing in the natural environment. This work could help us to fully understand the photoreaction processes concerning Fe(III)-Pyr complex and its potential for the degradation of pollutants in the natural surface and atmosphere water environment under solar irradiation.

\section{Acknowledgements}

This work was supported by the National Natural Science Foundation of PR China (Grant No. 20777057), the Major State Basic Research Development Program of China (973 Program) (No. 2008CB418105), China Postdoctoral Science Foundation funded project and the Scientific Research Foundation for the Returned Overseas Chinese Scholars, State Education Ministry. Authors gratefully acknowledge the Ministry of Education of the PR of China for financially supporting Dr. Changbo Zhang to stay at the Blaise Pascal University in Clermont-Ferrand, France.

\section{References}

[1] E.M. Thurman, Organic Geochemistry of Natural Waters, Martinus Nijhoff/Dr. W. Junk Publishers, 1985, p. 497.

[2] E.M. Perdue, E.T. Gjessing (Eds.), Life Sciences Research Report 48: Organic acids in aquatic ecosystems. Report on the Dehlem Workshop on Organic Acids in Aquatic Ecosystems Berlin, 1989, May 7-12, 1990, 345.

[3] R.W. Talbot, B.W. Mosher, B.G. Heikes, D.J. Jacob, J.W. Munger, B.C. Daube, W.C. Keene, J.R. Maben, R.S. Artz, Carboxylic acids in the rural continental atmosphere of the eastern United States during SCAPE, J. Geophys. Res. 100 (1995) 9335-9343.

[4] R.W. Talbot, J.D. Bradshaw, S.T. Sandholm, S. Smyth, D.R. Blake, N.R. Blake, G.W. Sachse, J.E. Collins, B.G. Heikes, B.E. Anderson, G.L. Gregory, H.B. Singh, B.L. Lefer, A.S. Bachmeier, Chemical characteristics of continental outflow over the tropical South Atlantic Ocean from Brazil and Africa, J. Geophys. Res. 101a (1996) 24187-24202.

[5] R.W. Talbot, J.E. Dibb, K.I. Klemm, J.D. Bradshaw, S.T. Sandholm, D.R. Blake, G.W. Sachse, J.E. Collins, B.G. Heikes, G.L. Gregory, B.E. Anderson, H.B. Singh, D.C. Thornton, J.T. Merrill, Chemical characteristics of continental outflow from Asia to the troposphere over the western Pacific Ocean during September-October 1991: results from PEM-West A: Pacific Exploratory Mission-West Phase A, J. Geophys. Res. 101b (1996) 1713-1725.

[6] R.W. Talbot, J.E. Dibb, B.L. Lefer, J.D. Bradshaw, S.T. Sandholm, D.R. Blake, N.J Blake, G.W. Sachse, J.E. Collins, B.G. Heikes, J.T. Merrill, G.L. Gregory, B.E. Anderson, H.B. Sing, D.C. Thornton, A.R. Bandy, R.F. Pueschel, Chemical characteristics of continental outflow from Asia to the troposphere over the western Pacific Ocean during February-March 1994: results from PEM-West B, J. Geophys. Res. 102a (1997) 28255-28274.

[7] R.W. Talbot, J.E. Dibb, B.L. Lefer, E. Scheuer, J.D. Bradshaw, S.T. Sandholm, S. Smyth, D.R. Blake, N.J. Blake, G.W. Sachse, J.E. Collins, G.L. Gregory, Large-scale distributions of tropospheric nitric, formic, and acetic acids over the western Pacific basin during wintertime, J. Geophys. Res. 102b (1997) 28303-28313.

[8] A. Chebbi, P. Carlier, Carboxylic acids in the troposphere, occurrence, source and sinks: a review, Atmos. Environ. 30 (1996) 4233-4249.

[9] N. Kumar, U.C. Kulshreshta, A. Saxena, K.M. Kumari, S.S. Srivastava, Effect of antropogenic activity on formate and acetate levels in precipitation at four sites in Agra, India, Atmos. Environ. 27B (1993) 87-91.

[10] S.F. Guiang, S.V. Krupa, G.C. Pratt, Measurements of S(IV) and organic anions in Minnesota rain, Atmos. Environ. 18 (1984) 1677-1682.

[11] P. Khare, G.S. Satsangi, N. Kumar, K.M. Kumari, S.S. Srivastava, HCHO, HCOOH and $\mathrm{CH}_{3} \mathrm{COOH}$ in air and rain water at a rural tropical site in north central India, Atmos. Environ. 31 (1997) 3867-3875.

[12] R. Sempere, K. Kawamura, Low molecular weight dicarboxylic acids and related polar compounds in the remote marine rain samples collected from western pacific, Atmos. Environ. 30 (1996) 1609-1619.

[13] D.W. Gunz, M.R. Hoffmann, Field investigations on the snow chemistry in central and southern California II Carbonyls and carboxylic acids, Atmos. Environ. 24A (1990) 1673-1684.

[14] A. Limbeck, H. Puxbaum, Organic acids in continental background aerosols, Atmos. Environ. 33 (1999) 1847-1852.

[15] K. Kawamura, R. Semere, Y. Imai, Y. Fujii, M. Hayashi, Water soluble dicarboxylic acids and related compounds in Antarctic aerosols, J. Geophys. Res. 101 (1996) 18721-18728.

[16] A.H. Khwaja, Atmospheric concentration of carboxylic acids and related compounds at a semiurban site, Atmos. Environ. 29 (1995) 127-139.

[17] D. Grosjean, Organic acids in southern California air: ambient concentration, mobile source emissions, in situ formation and removal processes, Environ. Sci. Technol. 23 (1989) 1506-1514.

[18] N. Kumar, U.C. Kulshresthau, P. Khare, A. Saxena, K.M. Kumari, S.S. Srivastava Measurements of formic and acetic acid levels in the vapour phase at Dayalbach, Agra, India, Atmos. Environ. 30 (1996) 3545-3550.

[19] D. Grosjean, Formic acid and acetic acid measurements during the southern California air quality study, Atmos. Environ. 24A (1990) 2699-2702.

[20] W.R. Hartmann, M.O. Andreae, G. Helas, Measurements of organic acids over Central Germany, Atmos. Environ. 23 (1989) 1531-1533.

[21] M.O. Andreae, R.W. Talbot, S.M. Li, Atmospheric measurements of pyruvic and formic acid, J. Geophys. Res. 92 (1987) 6635-6641.

[22] K. Kawamura, S. Steinberg, I.R. Kaplan, Concentrations of monocarboxylic and dicarboxylic acids and aldehydes in southern California wet precipitations: comparison of urban and nonurban samples and compositional changes during scavenging, Atmos. Environ. 30 (1996) 1035-1052.

[23] A. Mellouki, Y.J. Mu, On the atmospheric degradation of pyruvic acid in the gas phase, J. Photochem. Photobiol. A: Chem. 157 (2003) 295-300.

[24] X.Z. Fan, B. Lu, A.J. Gong, Dynamics of solar light photodegradation behavior of atrazine on soil surface, J. Hazard. Mater. 117 (2005) 75-79.

[25] T.M. Ward, J.B. Weber, Aqueous solubility of alkylamino-S-triazine as a function of pH and molecular structure, J. Agric. Food Chem. 16 (1968) 959-961.

[26] N. Chramosta, J. de Laat, M. Dore, H. Suty, M. Pouillot, Study of degradation of triazines by kinetic $\mathrm{O}_{3} / \mathrm{H}_{2} \mathrm{O}_{2}$ and $\mathrm{O}_{3}$ and oxidation byproducts, Water Supply 11 (1993) 177-185.

[27] D.R.U. Knappe, V.L. Snoeyink, P. Roche, M.J. Prados, M.M. Bourbigot, Atrazine removal by preloaded GAC, J. Am. Water Works Assoc. 91 (1999) 97-109. 
[28] G.Y.S. Chan, M.J. Hudson, N.S. Isaacs, Degradation of atrazine by hydrolysis and by hydroxyl radicals, J. Phys. Org. Chem. 5 (1992) 600-608.

[29] S. Nélieu, L. Kerhoas, J. Einhorn, Degradation of atrazine into ammeline by combined ozone/hydrogen peroxide treatment in water, Environ. Sci. Technol. 34 (2000) 430-437.

[30] S.M. Arnold, W.J. Hickey, R.F. Harris, Degradation of atrazine by Fenton's reagent: condition optimization and product quantification, Environ. Sci. Technol. 29 (1995) 2083-2089.

[31] C. Petrier, B. David, S. Laguian, Ultrasonic degradation at $20 \mathrm{kHz}$ and $500 \mathrm{kHz}$ of atrazine and pentachlorophenol in aqueous solution: preliminary results, Chemosphere 32 (1996) 1709-1718.

[32] V. Maurino, C. Minero, E. Pelizzeti, N. Serpone, in: E. Pelizzeti (Ed.), Fine Particles Science and Technology, Kluwer Academic Publishers, Dordrecht, MA, 1996, pp. 707-718.

[33] C. Minero, E. Pellizzetti, S. Malato, J. Blanco, Large solar plant photocatalytic water decontamination: degradation of atrazine, Sol. Energy 56(1996) 411-419.

[34] I. Texier, J. Ouazzani, J. Delaire, C. Giannotti, Study of the mechanisms of the photodegradation of atrazine in the presence of two photocatalysts: $\mathrm{TiO}_{2}$ and $\mathrm{Na}_{4} \mathrm{~W}_{10} \mathrm{O}_{32}$, Tetrahedron 55 (1999) 3401-3412.

[35] E. Pellizzetti, V. Maurino, C. Minero, V. Carlin, M.L. Tosato, E. Pramauro, O. Zerbinati, Photocatalytic degradation of atrazine and other S-triazine herbicides, Environ. Sci. Technol. 24 (1990) 1559-1565.
[36] E.B. Marianne, S. Barbara, Atrazine degradation in irradiated iron/oxalate systems: effects of pH and oxalate, Environ. Sci. Technol. 33 (1999) 2418-2424.

[37] J.G. Calvert, J.N. Pitts, Photochemistry, John Wiley \& Sons, New York, 1966, p. 783

[38] Y.G. Zuo, Kinetics of photochemical/chemical cycling of iron coupled with organic substances in cloud and fog droplets, Geochim. Cosmochim. Acta 59 (1995) 3123-3130.

[39] E. Oliveros, O. Legrini, M. Hohl, T. Muller, A. Braun, Industrial waste water treatment: large scale development of a light-enhanced Fenton reaction, Chem. Eng. Process. 36 (1997) 397-405.

[40] O. Abida, Impact complexes of iron and the solar light on the fate of pollutants in the aquatic environment. Ph.D. Thesis, Université Blaise Pascal, ClermontFerrand, France, 2005.

[41] O. Abida, G. Mailhot, M. Litter, M. Bolte, Impact of iron-complex (Fe(III)-NTA) on photoinduced degradation of 4-chlorophenol in aqueous solution, Photochem. Photobiol. Sci. 5 (2006) 395-402.

[42] M. Parazols, Physico-chemical characterization and reactivity of the aqueous phase of clouds taken at the summit of Puy de Dôme. Ph.D. Thesis, Université Blaise Pascal, Clermont-Ferrand, France, 2007.

[43] L. Wang, C.B. Zhang, F. Wu, N.S. Deng, E.M. Glebov, N.M. Bazhin, Determination of hydroxyl radicals from photolysis of $\mathrm{Fe}(\mathrm{III})$-pyruvate complexes in homogeneous aqueous solution, React. Kinet. Catal. Lett. 89 (2006) 183-192. 